\title{
Trends of the culinary herbs diversity research and their use in green plantations
}

\author{
Aušra Budrienė, Idalija Buzienė, Jolanta Margelienė, Laima Markevičienė, \\ Nijolė Maročkienè \\ Kauno kolegija/ University of applied sciences, Faculty of Technologies and landscaping, \\ Department of green plantations and agro technologies. \\ Address: Pramones str. 22, \\ Kaunas, Institute of Horticulture Lithuanian Research Centre for Agriculture and Forestry. \\ Address: Kauno str. 30, Babtai
}

\begin{abstract}
In recent times, due to the globalization the fashion of plant cultivation has been changing as well; imported, decorative acclimatized culinary herbs have been penetrating, therefore, new tasks to integrate them into the traditional plantations have been arising.

The main aim of the paper is to select culinary herbs for the design solutions having different purpose and adapted to different environmental conditions, to reveal the possibilities to use the best properties of these plants, to help the persons interested in the use of culinary herbs to decide on the proper plant selection, to provide recommendations on the combination and composition possibilities of these plants.

The authors of the article have analyzed and evaluated the research carried out in Lithuania related to the issues of culinary herb cultivation. In the Institute of Horticulture Lithuanian Research Centre for Agriculture and Forestry 24 species of culinary herbs are cultivated. By analyzing the culinary herbs cultivation technologies, plant bio ecology and morphology as well as priority propagation techniques have been evaluated; decorative properties of herbs and the possibility of their use in green plantations have been assessed.
\end{abstract}

Keywords: globalization, culinary herbs, bio ecology, plantations.

\section{INTRODUCTION}

A person gets to know his surroundings through the senses: sight, smell, taste, hearing and touch. There are more than 1000 species of plants, the parts of which are used as spices, in the world. About 100 species of culinary herbs are cultivated in Lithuania. In XI-XIII centuries Europeans started using lavender, rosemary, thyme, etc. as culinary spices [1].

The first data about the Renaissance garden plants was found in Lithuania in 1542-1547 in the description of Radvilos palace garden in Vilnius. Besides local trees and fruit trees, decorative, culinary plants such as hyssop, rosemary, lavender are mentioned.

In the pre-war Lithuania there was no a single house or a homestead without a flower garden. It was the centerpiece of the entire homestead. Flower gardens were created for the beauty of the flowers, for different rites, as well as medicines and spices. An absinth was always grown under the windows, because its smell scared flies, thus, when leaving open windows they did not fly inside. Every homestead was decorated by peonies; according to the elders they drove away the fear. Lithuanians could not do without lavender, it was perfect for scenting bed and the clothes, seasoning meat and it was believed to bring happiness. They were dried and carried to the bath, their smell perfectly relaxed after a hard day. Wormwood was cultivated for medical purposes, they were used for stomach ailments. [6].

Mint, spearmint, lemon balm, thyme, basil, oregano, hyssop, sage, Santa (catnip - Nepeta L.) were cultivated in gardens. Gardens could not do without „,cibuliuku““ (onions), „tribulkų“ (chives Allium schoenoprasum L.) [2]. Medicinal herbs such as fleabane (Inula L.), absinth (Artemisia absinthium L.) were cultivated not only in the garden, but also in other parts of the homestead. The flower beds were established under the windows to produce nice smell, mostly L-shaped in the southern and eastern side, over the entire house side, in the rear side of the house [5].

During the last years there has been an increasing tendency to promote, propagate the use of herbs in 
the green plantations of homesteads, country tourism homesteads or other territories, although their versatile benefits on a human being have long been recognized. Culinary herbs descriptions are presented K.K, Vilkonis works [8].

Culinary herbs are not widely grown in flower beds, because most of them are not as good looking and decorative as imported plants. However, for smaller homesteads, in order to have splendid flower gardens, and at the same time a few culinary herbs after combining them, we can have decorative combinations.

The growing demand for non-traditional, culinary, aromatic, medicinal plants encourages investigating new plant species and their application possibilities. In Lithuania culinary herbs are not widely cultivated although many of them grow well in the natural environment conditions.

In the culinary herbs collection of the Institute of Horticulture of Lithuanian Research Centre for Agriculture and Forestry long-term phenological observations of culinary herbs - plant growth, development and adaptation have been carried out. The best harvesting time of raw material and yield is identified. Studies on the quality of the raw material are performed [3]. Valuable selection of individuals, formation of populations are carried out. During individual selection and after the studies on economical value, in 1999 the smoked coriander breeding line No. 20 was given the name of the strain 'Raslè', in 2005 the chives breeding line No. 028 was given the name of the strain 'Aliai' [4].

Possibilities for culinary herbs adaptation in green plantations were little studied. When growing herbs for green plantations, it is essential to select perspective herb species and varieties for cultivation in Lithuania.

The aim of the research is to investigate and evaluate morphological and bio-ecological characteristics of over ground parts of culinary herbs cultivated in Lithuanian local soils conditions, their cultivation and application in green plantations.

\section{MATERIALS AND METHODS}

The studies were performed at the Institute of Horticulture LRCAF in the test field of crop rotation in 2013-2014. The soil - sandy on light loamy calcaric shallow luvisol (Idg8-k / Calc(ar Epihypogleyc Luvisols - LVg-p-w-cc) (Buivydaitė et al., 2001). Plant preceding crop - black fallow land. 26 species of perennial aromatic herbs were cultivated. In 2013 seedlings were planted in $70 \mathrm{~cm}$ spacing rows and $30 \mathrm{~cm}$ between plants on flat surface in the second decade of May. Accounting field area $-9,6 \mathrm{~m}^{2}$. Test versions were repeated three times. Observations of plant height, flowering time and duration were carried out.

Growing of herbaceous plants in green plantations, their combinations with perennial flowers and decorative shrubs were studied in Kauno kolegija in 2012-2013.

Sixteen different species of perennial culinary herbs of different growth were selected for the investigation: Inula helenium L., Artemisia dracunculus L., Agastache foeniculum L., Hyssopus officinalis L, Nepeta cataria L., Satureja montana L., Thymus serpyllum L., Origanum vulgare L., Mentha x piperita L., Monarda didyma L., Melissa officinalis L., Lavandula angusitifolia, Salvia officinalis L., Allium nutans L., Allium ursinum L.

Culinary herbs were cultivated following the garden plants growing technology approved in the Institute of Horticulture Lithuanian Research Centre for Agriculture and Forestry.

During every year of research in the group of perennial and annual culinary herbs species seasonal development phases were recorded once a week. The beginning of a plant vegetation and flowering time were evaluated. Biometric measurements were carried out once every vegetation during massive flowering time of plants. During the years of investigations the average air temperature during the growing season of perennial plants was lower than the average. There was enough precipitation for plants to grow. The height, flowering time and the application of culinary herbs in green plantations were assessed following the methodology prepared by Jonas Vaidelys (2005) in the publication „Methodology of ornamental herbaceous plant phenological observations, biometric measurements and the assortment $\mathrm{f}$ formation " [7]:

Plant height was measured during the flowering time of a plant from the ground to the highest point. It is evaluated in centimeters, providing data about plants their height can be decoded. Florists grade the height of flowers in $20 \mathrm{~cm}$ intervals. The following height categories of flowers can be distinguished:

$0-20 \mathrm{~cm}$ - carpet dwarf;

$21-41 \mathrm{~cm}$ - carpet tall;

$42-60 \mathrm{~cm}$ - average height;

$61-80 \mathrm{~cm}$ - semi-tall;

$81-100 \mathrm{~cm}-$ tall;

101 and more - very tall.

Flowering duration is assessed the following way:

1-5 days;

6-10 days;

11-20 days;

21-30 days;

31-50 days;

51 and more days. 


\section{Assessment of the application possibilities}

The following plant application positions can be distinguished: for beds (rabates), edges (boarders), raised beds, parterres, groups, single growing (solitaires), flower boxes, vases, growing in pots, balconies, hedges, cemeteries, water pools, water pool coastlines, rockery, and picking.

The following applications are distinguished: very limited application possibilities (1-3 application positions), limited application possibilities $(4-6$ application positions), medium application possibilities ( $7-9$ application positions), broad application possibilities $(10-12$ application positions), and very broad application possibilities (13 - 15 application positions).

\section{RESULTS AND DISCUSSION}

Table 1 presents morphological and bio ecological characteristics of culinary herbs.

TABLE 1.

MORPHOLOGICAL AND BIO ECOLOGICAL CHARACTERISTICS OF CULINARY HERBS (BABTAI, 2013-2014)

\begin{tabular}{|c|c|c|c|c|c|}
\hline \multirow{2}{*}{$\begin{array}{c}\text { The botanical name of } \\
\text { the plant }\end{array}$} & \multicolumn{2}{|c|}{$\begin{array}{c}\text { Aboveground part } \\
\text { of the plant }\end{array}$} & \multirow{2}{*}{ 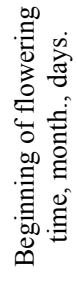 } & \multirow{2}{*}{ 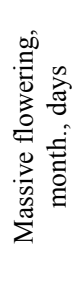 } & \multirow{2}{*}{ 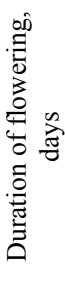 } \\
\hline & $\begin{array}{l}\text { Height, } \\
\mathrm{cm}\end{array}$ & $\begin{array}{l}\text { Diameter, } \\
\mathrm{cm}\end{array}$ & & & \\
\hline Allium nutans L. & 51,5 & 69,8 & 0714 & 0725 & 30 \\
\hline $\begin{array}{l}\text { Allium schoenoprasum } \\
\text { L. }\end{array}$ & 54,8 & 57,6 & 0605 & 0622 & 33 \\
\hline Allium angulosum $\mathrm{L}$. & 53,5 & 59,3 & 0618 & 0704 & 37 \\
\hline Allium ursinum L. & 48,4 & 55,5 & 0514 & 0526 & 27 \\
\hline Inula helenium $\mathrm{L}$. & 195,7 & 89,1 & 0708 & 0720 & 56 \\
\hline $\begin{array}{l}\text { Artemisia abrotanum } \\
\text { L. }\end{array}$ & 137,6 & 86,2 & 0817 & 0903 & 44 \\
\hline $\begin{array}{l}\text { Artemisia absinthium } \\
\text { L. }\end{array}$ & $\begin{array}{c}153 \\
5 \\
\end{array}$ & 104,3 & $\begin{array}{l}08 \\
06 \\
\end{array}$ & $\begin{array}{l}08 \\
28 \\
\end{array}$ & 47 \\
\hline $\begin{array}{l}\text { Sanquisorba officinalis } \\
\text { L. }\end{array}$ & 62,2 & 61,5 & $\begin{array}{l}06 \\
26\end{array}$ & $\begin{array}{l}07 \\
09\end{array}$ & 33 \\
\hline Geum urbanum L. & 42,7 & 48,9 & $\begin{array}{l}06 \\
04\end{array}$ & $\begin{array}{l}06 \\
26\end{array}$ & 45 \\
\hline Hyssopus officinalis L. & 65,6 & 67,8 & $\begin{array}{l}06 \\
21 \\
\end{array}$ & $\begin{array}{l}07 \\
15 \\
\end{array}$ & 52 \\
\hline Salvia officinalis L. & 62,3 & 67,4 & $\begin{array}{l}06 \\
12 \\
\end{array}$ & $\begin{array}{l}06 \\
29\end{array}$ & 35 \\
\hline Melissa officinalis L. & 77,4 & 84,2 & $\begin{array}{l}07 \\
23 \\
\end{array}$ & $\begin{array}{l}08 \\
18 \\
\end{array}$ & 46 \\
\hline Origanum vulgare L. & 72,7 & 61,5 & $\begin{array}{l}06 \\
17 \\
\end{array}$ & $\begin{array}{l}07 \\
02 \\
\end{array}$ & 40 \\
\hline Thymus vulgare L. & 23,5 & 38,6 & $\begin{array}{l}06 \\
04\end{array}$ & $\begin{array}{l}06 \\
26\end{array}$ & 30 \\
\hline
\end{tabular}

\begin{tabular}{|c|c|c|c|c|c|}
\hline Thymus serpyllum L. & 31,3 & 54,2 & $\begin{array}{l}06 \\
20\end{array}$ & $\begin{array}{l}07 \\
08\end{array}$ & 42 \\
\hline Satureja montana L. & 37,8 & 52,7 & $\begin{array}{l}07 \\
10\end{array}$ & $\begin{array}{l}08 \\
04\end{array}$ & 57 \\
\hline Nepeta pannonica L. & 38,6 & 41,4 & $\begin{array}{l}05 \\
26\end{array}$ & $\begin{array}{l}06 \\
14\end{array}$ & 74 \\
\hline Marrubium vulgare L. & 56,4 & 68,5 & $\begin{array}{l}06 \\
18\end{array}$ & $\begin{array}{l}07 \\
11\end{array}$ & 65 \\
\hline Mentha piperita $\mathrm{L}$. & 53,8 & 58,4 & $\begin{array}{l}07 \\
13\end{array}$ & $\begin{array}{l}08 \\
01\end{array}$ & 52 \\
\hline Mentha spicata $\mathrm{L}$. & 66,7 & 55,2 & $\begin{array}{l}06 \\
26\end{array}$ & $\begin{array}{l}07 \\
21\end{array}$ & 58 \\
\hline $\begin{array}{l}\text { Agastache foeniculum } \\
\text { L. }\end{array}$ & 72,5 & 65,8 & $\begin{array}{l}06 \\
14 \\
\end{array}$ & $\begin{array}{l}07 \\
19 \\
\end{array}$ & 64 \\
\hline Salvia sclarea L. & 93,3 & 78,2 & $\begin{array}{l}06 \\
27\end{array}$ & $\begin{array}{l}07 \\
19\end{array}$ & 47 \\
\hline Monarda didyma $\mathrm{L}$. & 46,8 & 63,2 & $\begin{array}{l}06 \\
29\end{array}$ & $\begin{array}{l}07 \\
19\end{array}$ & 63 \\
\hline $\begin{array}{l}\text { Nepeta cataria } \text { L.var. } \\
\text { citriodora } \text { Becker }\end{array}$ & 88,6 & 79,5 & $\begin{array}{l}07 \\
04 \\
\end{array}$ & $\begin{array}{l}07 \\
26 \\
\end{array}$ & 40 \\
\hline $\begin{array}{l}\text { Lavandula angustifolia } \\
\text { L. }\end{array}$ & 50,4 & 49,6 & $\begin{array}{l}06 \\
20\end{array}$ & $\begin{array}{l}07 \\
09\end{array}$ & 46 \\
\hline Hierochoe odorata L. & 51,8 & 41,7 & $\begin{array}{l}05 \\
16\end{array}$ & $\begin{array}{l}06 \\
18\end{array}$ & 52 \\
\hline
\end{tabular}

Out of the investigated culinary herbs the most widely studied were the plants of Labiatae (Lamiaceae) family -16 species.

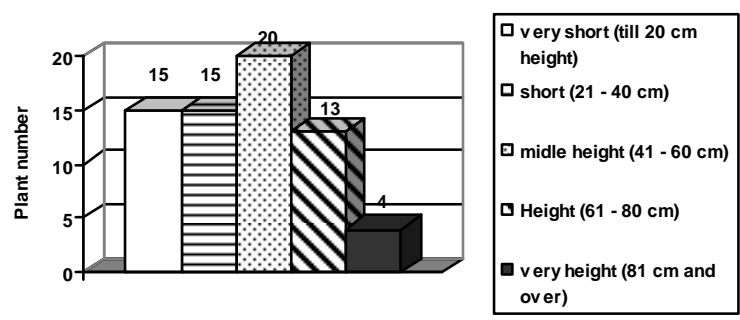

Fig. 1. The height of culinary herbs

The majority of plants are of medium height - 20 species: Allium schoenoprasum L., Artemisia absinthium L., Lavandula angustifolia L. etc. The least number of plants are very high herbs -4 species: Inula helenium L., Artemisia abrotanum L. etc. (Figure 1).

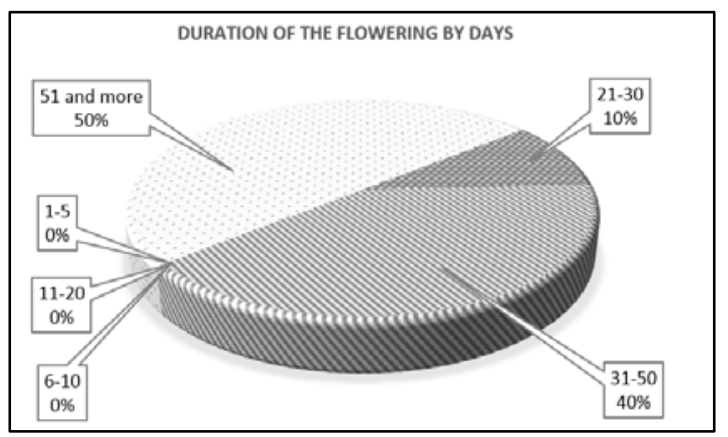

Fig. 2. Herbs distribution by flowering time 
The longest flowering time of studied plants is 51 days and more, this makes 50 percent of all investigated plants (Figure 2). This feature of culinary herbs is positive and it provides excellent possibilities to use these plants in green plantations.

TABLE 2.

THE USE OF CULINARY HERBS IN GREEN PLANTATIONS

\begin{tabular}{|c|c|c|c|c|c|c|c|c|c|c|c|c|c|}
\hline No & $\begin{array}{l}\text { The botanical } \\
\text { name of the } \\
\text { plant }\end{array}$ & $\begin{array}{l}n \\
\overrightarrow{0} \\
\tilde{D}\end{array}$ & 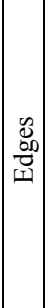 & 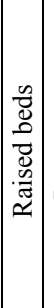 & 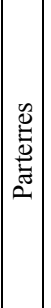 & 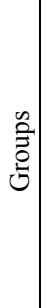 & 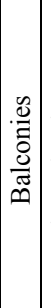 & 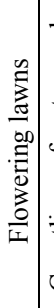 & 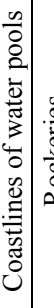 & 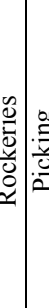 & & & 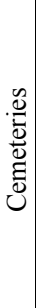 \\
\hline 1. & Inula helenium L. & & & $\mathrm{x}$ & & $\mathrm{x}$ & & & $\mathrm{x}$ & & $x$ & & \\
\hline 2. & $\begin{array}{l}\text { Artemisia } \\
\text { dracunculus L. }\end{array}$ & & & & & $\mathrm{x}$ & & $\mathrm{x}$ & & & & & \\
\hline 3. & $\begin{array}{l}\text { Agastache } \\
\text { foeniculum } \mathrm{L} .\end{array}$ & $\mathrm{x}$ & & $\mathrm{x}$ & & $\mathrm{x}$ & & $\mathrm{x}$ & & & \begin{tabular}{l|l}
$\mathrm{x}$ & 2
\end{tabular} & $\mathrm{x}$ & \\
\hline 4. & $\begin{array}{l}\text { Hyssopus } \\
\text { officinalis L. }\end{array}$ & & & & & $\mathrm{x}$ & & $\mathrm{x}$ & & & & & \\
\hline 5. & Nepeta cataria $\mathrm{L}$. & & & & & $\mathrm{x}$ & & $\mathrm{x}$ & & & & & \\
\hline 6. & $\begin{array}{l}\text { Satureja } \\
\text { montana L. }\end{array}$ & & $\mathrm{x}$ & & & & $\mathrm{x}$ & & & $\mathrm{x}$ & 2 & $\mathrm{x}$ & \\
\hline 7. & \begin{tabular}{|l} 
Thymus \\
serpyllum $\mathrm{L}$.
\end{tabular} & & $\mathrm{x}$ & & & & & $\mathrm{x}$ & & $\mathrm{x}$ & 2 & $\mathrm{x}$ & \\
\hline 8. & $\begin{array}{l}\text { Thymus citriodor } \\
\text { L. }\end{array}$ & & $\mathrm{x}$ & & & & $\mathrm{x}$ & & & $\mathrm{x}$ & & $\mathrm{x}$ & $\mathrm{x}$ \\
\hline 9. & $\begin{array}{l}\text { Origanum vulgare } \\
\text { L. }\end{array}$ & & $\mathrm{x}$ & & & $\mathrm{x}$ & & $\mathrm{x}$ & & $\mathrm{x}$ & $\begin{array}{ll}\mathrm{x} & 2\end{array}$ & $\mathrm{x}$ & \\
\hline 10. & $\begin{array}{l}\text { Mentha } x \text { piperita } \\
\text { L. } \\
\end{array}$ & & & & & $\mathrm{x}$ & & & & & & & \\
\hline 11. & \begin{tabular}{|l|} 
Monarda didyma \\
L.
\end{tabular} & & & & & $\mathrm{x}$ & & $\mathrm{x}$ & & & $\mathrm{x}$ & $\mathrm{x}$ & \\
\hline 12. & $\begin{array}{l}\text { Melissa officinalis } \\
\text { L. }\end{array}$ & & & & & $\mathrm{x}$ & & & & & & & \\
\hline 13. & $\begin{array}{l}\text { Lavandula } \\
\text { angusitifolia } \mathrm{L} \text {. }\end{array}$ & $\mathrm{x}$ & $\mathrm{x}$ & $\mathrm{x}$ & $\mathrm{x}$ & & $\mathrm{x}$ & $\mathrm{x}$ & & $\begin{array}{ll}\mathrm{x} & \end{array}$ & $\mathrm{x}$ & $\mathrm{x}$ & \\
\hline 14. & Salvia officinalis & & & $\mathrm{x}$ & & $\mathrm{x}$ & & $\mathrm{x}$ & & & $\mathrm{x}$ & $\mathrm{x}$ & \\
\hline 15. & Allium nutans L. & & $\mathrm{x}$ & & & & & & & $\mathrm{x}$ & & & \\
\hline 16. & Allium ursinum $\mathrm{L}$. & & & & & $\mathrm{x}$ & & $\mathrm{x}$ & & $\mathrm{x}$ & & & \\
\hline
\end{tabular}

The most culinary herbs used in green plantations are used for groups - 12 species, flowering lawns 10 species, pots -8 species and rockeries -7 species (Table 2).

The highest number of investigated culinary plant species (8) has limited application possibilities in green plantations ( $\operatorname{Pr} 4-6)$, and 7 species - very limited application (Pr 1-3) (Figure 3).

Lavandula angusitifolia L. has the biggest possibilities for the application in green plantations (9). 8 investigated plant species have medium possibilities for the application in green plantations, and 7 species - very limited application possibilities. It can be stated that possibilities for culinary herb application are much more limited than those of cultural decorative plants (Figure 4).

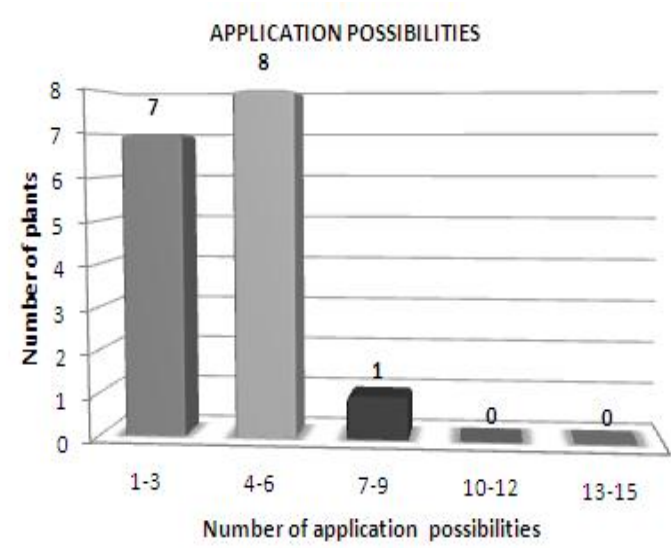

Fig. 3 Number of application possibilities

APPLICATION POSSIBILITIES

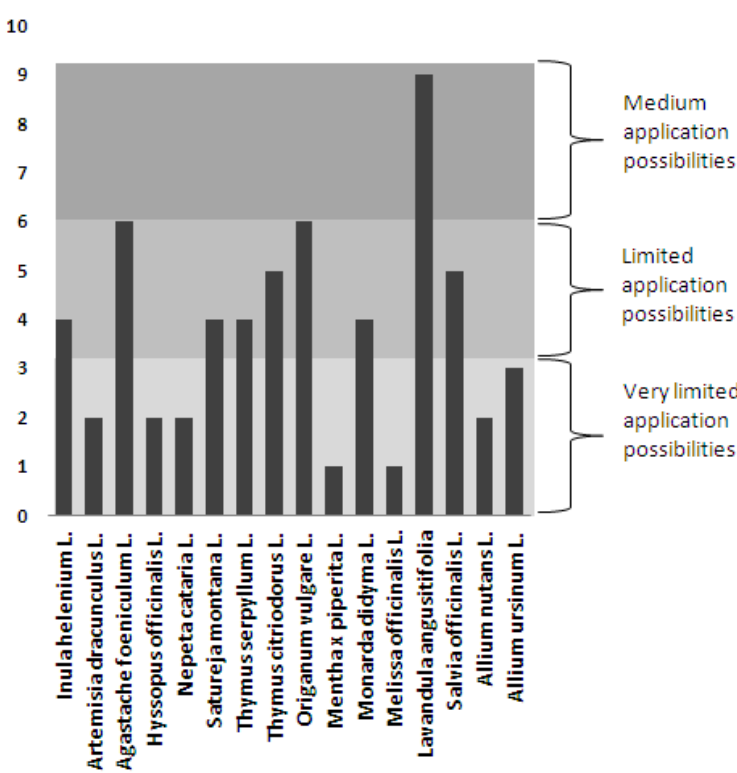

Fig 4. Possibilities for culinary herbs application in green plantations

Using the investigated species of culinary herbs 2 examples of flowerbeds designs (A and $\mathrm{B}$ ) have been created (Figure 5). 


\section{CONCLUSION}

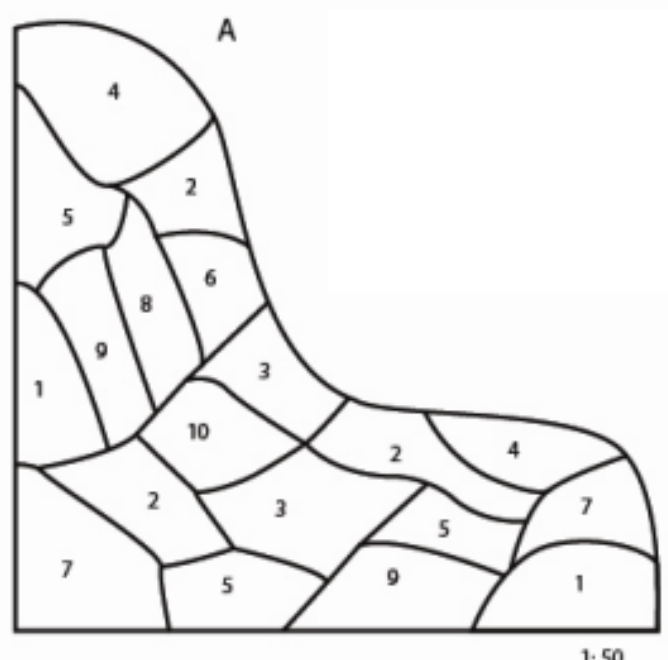

1. SALVIA OFFICINAUS'PURPURESCENS

2. MONARDA DIOYMAL

3. IRIS SIBIRICA L

4. LEVANDA OFFICINALUSL

5. ORIGAWUM VULGAREL

6. HYSOPUS OFFCINALUSL.

7. PGNNISETUM ALOPECURONDES HALMEN'

8. ARTEMISLAABSNTHIUML.

9. ALLUM OFLATUNENSEL

10. ECHNACEA PURPUREAL

B

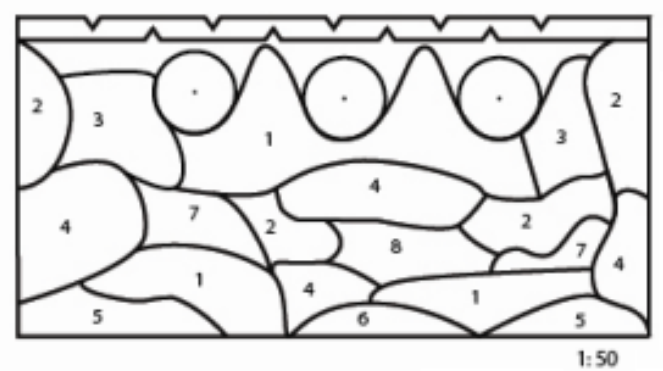

1. LAVANDA OFFICINAUSL.

2. SALVA OFFCINALIS PURPURESCENS

3. LATRUM SAUCARIA 'ROBERT'

4. PGNNISETUM ALOPECUPOIDES HALMEN

5. THYMUUS PRAECOX COCCNNEUS

6. ORIGANUM WIGARE'COMPACIA'

7. AGASTACHE FOENICULUML.

8. ORIGANUM WIGAREL.

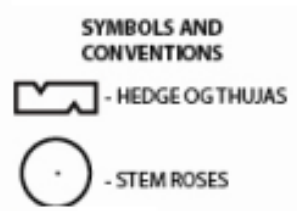

Fig 5. Designs of flower gardens of culinary herbs (A, B)
The analysis of bioecological-morphological characteristics of studied culinary plants indicates that majority of plants (20 species) are of medium height: Allium schoenoprasum L., Artemisia absinthium L., Lavandula angustifolia L. etc. The smallest number of plants (4 species) includes very tall culinary herbs: Inula helenium L., Artemisia abrotanum L. etc.

The duration of flowering time of 50 percent of all studied plants is 51 day and longer, therefore, this feature opens the possibilities to use these plants in green plantations.

The majority of investigated plants have limited application possibilities in green plantations (8), mostly 4 or 6 application positions. The biggest application possibilities (9) are possessed by Lavandula angusitifolia L. Therefore, it is possible to conclude that the application possibilities for culinary herbs are much lower than for cultural decorative plants.

Two examples of flowerbeds including culinary herbs recommended for green plantations have been designed because nowadays it is very popular to cultivate aromatic spices in living environment.

\section{REFERENCES}

[1] Erik van Wyk B., Michael W. Medicinal plants of the world. 2010.

[2] Bomblauskas J., Žumbakienẻ R. Žemaitijos tradicinè kaimo architektūra. 2009.

[3] Dambrauskienè E. Aromatinių ir vaistinių augaly biocheminiu tyrimu raida Lietuvos sodininkystès ir daržininkystès institute. Sodininkystè ir daržininkystè. 2008.

[4] Maročkienė N. Prieskoniniai augalai. 2003.

[5] Ragažinskienė O., Rimkienẻ S., Sasnauskas V. Vaistinių augalų enciklopedija. 2005.

[6] Purvinas M. Mažosios Lietuvos tradicinè kaimo architektūra. 2008.

[7] Vaidelys J. Dekoratyviụju žolinių augalu fenologinių stebejimų, biometrinių matavimų ir sortimento sudarymo metodika. 2005.

[8] Vilkonis K.K. Lietuvos žaliasis rūbas. 2001. 